\author{
JURNAL EINSTEIN \\ Jurnal Hasil Penelitian Bindang Fisika \\ Available online http://jurnal.unimed.ac.id/2012/index.php/inpafi \\ e-issn: $2407-747 x$, p-issn $2338-1981$
}

\title{
KARAKTERISASI BIOPLASTIK DARI PELEPAH KELAPA SAWIT DENGAN PENAMBAHAN VARIASI PERBANDINGAN MAIZENA DAN GLISERIN
}

\author{
Ahmad Ramadhan, Dian Wardana, Rahayu, Vina Fadhilla, Yuli Santika Manalu, dan \\ Eddiyanto
}

\author{
Fakultas Matematika dan Ilmu Pengetahuan Alam, Universitas Negeri Medan, Indonesia \\ ahmad.rar18@gmail.com
}

Diterima April 2017; Disetujui Mei 2017; Dipublikasikan Juni 2017

\begin{abstract}
ABSTRAK
Telah dilakukan penelitian mengenai karakterisasi bioplastik dari pelepah kelapa sawit yang bertujuan untuk melihat pengaruh penambahan variasi perbandingan maizena dan gliserin pada sampel. Dimana pelepah kelapa sawit yang mengandung selulosa, dalam penelitian ini telah disintesis menjadi bioplastik melalui proses delignifikasi dan bleaching cacahan pelepah kelapa sawit kering. Selulosa yang didapat diasetilasi untuk mengubahnya menjadi selulosa asetat. Selulosa asetat yang terbentuk selanjutnya disintesis dengan penambahan berbagai variasi perbandingan maizena dan gliserin. Karakterisasi bioplastik dilakukan dengan menggunakan alat universal testing machine yang meliputi kuat tarik dan elongasi, sedangkan untuk uji degradasi menggunakan metode gravimetri. Dari hasil pengujian, didapatkan nilai kuat tarik, elongasi dan degradasi tertinggi secara berurut yaitu sebesar 8,96 $\mathrm{MPa}, 23,61 \%$ dan $91 \%$.
\end{abstract}

Kata kunci : Bioplastik, Pelepah Kelapa sawit, Maizena, Gliserin, Karakterisasi.

\section{PENDAHULUAN}

Plastik memiliki peranan yang sangat penting dalam kehidupan manusia, sebagai media pengemas plastik memiliki beberapa keunggulan diantaranya bobot yang ringan, kuat, transparan dan harganya yang dapat dijangkau semua kalangan masyarakat. Namun penggunaan plastik sebagai bahan pengemas menghadapi berbagai persoalan lingkungan, yaitu sulit untuk didaur ulang dan tidak dapat diuraikan secara alami oleh mikroba di dalam tanah, sehingga terjadi penumpukan sampah plastik yang dapat menyebabkan pencemaran dan kerusakan bagi lingkungan ( Syamsir, 2008).
Kelemahan lain adalah bahan utama pembuat plastik yang berasal dari minyak bumi, yang keberadaannya semakin menipis dan tidak dapat diperbaharui.

Berdasarkan asumsi Kementerian Lingkungan Hidup (KLH), setiap hari penduduk Indonesia menghasilkan $0,8 \mathrm{~kg}$ sampah per orang atau secara total sebanyak 189 ribu ton sampah/hari. Dari jumlah tersebut $15 \%$ berupa sampah plastik atau sejumlah 28,4 ribu ton sampah plastik/hari (Pahlevi, 2012). Sebagai gambaran, untuk membuat $1 \mathrm{~kg}$ plastik memerlukan $1,75 \mathrm{~kg}$ minyak bumi, untuk memenuhi kebutuhan bahan bakunya 
maupun kebutuhan energi prosesnya (Kumar, dkk., 2011). Seiring dengan persoalan ini, maka penelitian bahan kemasan (plastik) diarahkan pada bahanbahan organik, yang dapat dihancurkan secara alami dan mudah diperoleh (Pranamuda, 2009).

Salah satu solusi yang dapat mengatasi permasalahan ini adalah penggunaan plastik Biodegradable (Bioplastik). Plastik biodegradable adalah plastik yang dapat digunakan seperti layaknya plastik konvensional, namun akan hancur terurai oleh aktivitas mikroorganisme menjadi air dan karbondioksida setelah habis terpakai dan dibuang ke lingkungan. Karena sifatnya yang dapat kembali ke alam, maka dikategorikan sebagai plastik yang ramah lingkungan (Charles, 1999). Berdasarkan bahan baku yang dipakai, plastik biodegradable dibagi menjadi dua kelompok, yaitu kelompok dengan bahan baku petrokimia dan kelompok dengan bahan baku produk tanaman seperti pati dan selulosa (Firdaus, 2004).

Bahan yang menjadi pusat kajian pada penelitian ini adalah plastik dengan bahan baku selulosa dari pelepah kelapa sawit. Karena Pertumbuhan industri sawit di Indonesia saat ini telah menunjukkan perkembangan yang sangat cepat. Dari perkebunan sawit, dalam satu tahun akan dihasilkan 6,3 ton pelepah sawit per hektar(Litbang Deptan, 2010). Provinsi Riau tercatat sebagai wilayah yang memiliki perkebunan sawit terluas di Indonesia yaitu 2,25 juta hektar (Badan Pusat Statistik Riau, 2011).

Pelepah sawit merupakan limbah padat sawit yang sangat potensial untuk digunakan sebagai bahan baku utama selulosa(Padil, 2010). Padil (2009) melaporkan komposisi selulosa, hemiselulosa, dan lignin pelepah sawit secara berturut-turut ; $34,89 \%, 27,14 \%$, dan $19,87 \%$.

Berdasarkan analisa kimia pelepah kelapa sawit tersebut, kandungan kimia terbanyak yaitu selulosa berpotensi untuk dijadikan bahan bioplastik. Polimer selulosa yang kuat apabila divariasikan dengan maizena yang berfungsi sebagai perekat dan gliserin sebagai plastisizer, hal ini sangat berpeluang untuk diubah menjadi bioplastik yang tidah kalah dengan plastik pada umumnya. Oleh karena itu, dalam penelitian ini akan dibahas tentang bagaimana pengaruh variasi yang ditambahkan dan hasil karakterisasi setiap variasi bioplastik yang disintesis, sehingga akan didapatkan komposisi atau variasi bioplastik terbaik.

\section{METODE PENELITIAN}

\section{Alat dan Bahan}

Alat yang digunakan dalam penelitian ini adalah Neraca Analitik, Cawan Petri, Gelas Ukur, Gelas Beaker, Hot Plate/Pemanas, Pengaduk, Pisau, Mesin Penghalus, Penyaring, Wadah, Pipet Tetes, Pipet Ukur, Kertas Saring, Corong, Termometer, Oven, Kaca Arloji, Sudip, Labu Ukur, Alat Universal Testing Machine. Sedangkan bahan yang digunakan adalah Pelepah Kelapa Sawit ( PKS ), Maizena, Gliserin, Asam Asetat Glasial, Asetat Anhidrat, Natrium Hidroksida, Asam Sulfat Pekat, Hidrogen Peroksida, Aquades, Kertas Universal.

\section{Prosedur Kerja}

Dalam penelitian ini terdapat 6 tahapan kerja, yaitu :

Tahap 1 : Persiapan Bahan Baku

Tahap 2 : Delignifikasi

Tahap 3 : Bleaching

Tahap 4 : Pembuatan Selulosa Asetat

Tahap 5 : Sintesis Bioplastik

Tahap 6 : Pengujian Bioplastik 


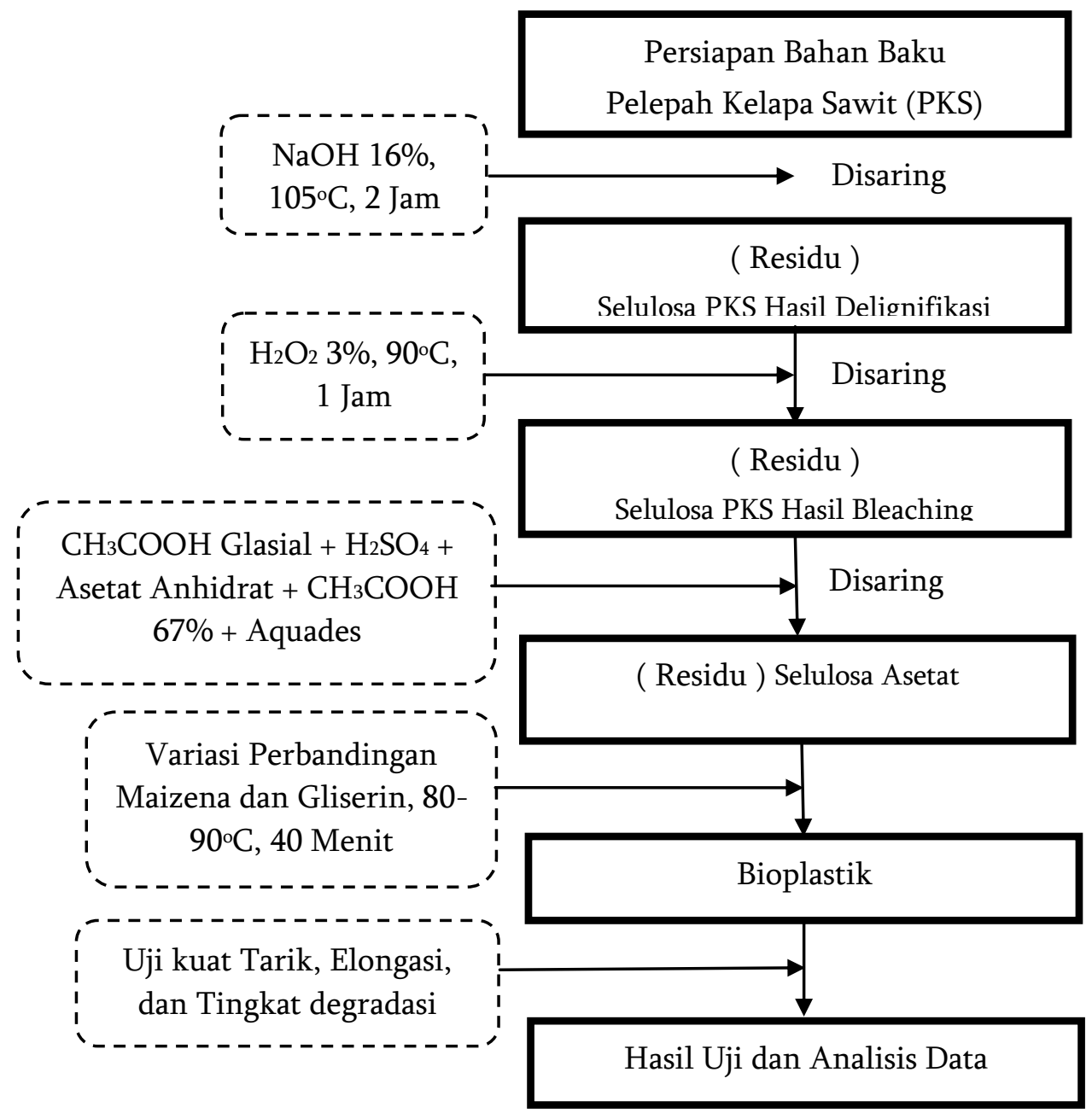

Gambar 1. Skema Prosedur Kerja

\section{Variabel Penelitian}

Perbandingan Selulosa Asetat (gram)

: Maizena (gram) : Gliserin (gram) yang digunakan adalah:

$4: 1: 1$

$4: 1: 2$

$4: 1: 3$
$4: 2: 2$

$4: 2: 3$

\section{HASIL DAN PEMBAHASAN}

Pada penelitian ini, pembahasan meliputi hasil uji kuat tarik, elongasi dan degradasi dari setiap variasi bioplastik.

Tabel 1. Hasil Pengujian Bioplastik

\begin{tabular}{|c|c|c|c|}
\hline Variasi & \multicolumn{3}{|c|}{ Nilai Uji } \\
\cline { 2 - 4 } $\begin{array}{c}\text { (Selulosa asetat : } \\
\text { Maizena : Gliserin) }\end{array}$ & Kuat Tarik (MPa) & Elongasi (\%) & Degradasi (\%) \\
\hline I $(4: 1: 1)$ & 8,32 & 22,92 & 91 \\
\hline II $(4: 1: 2)$ & 8,05 & 23,17 & 81 \\
\hline III $(4: 1: 3)$ & 7,57 & 23,61 & 83 \\
\hline IV $(4: 2: 1)$ & 8,96 & 22,75 & 89 \\
\hline
\end{tabular}




\begin{tabular}{|c|c|c|c|}
$\mathrm{V}(4: 2: 2)$ & 8,41 & 22,94 & 90 \\
\hline $\mathrm{VI}(4: 2: 3)$ & 8,09 & 23,45 & 87 \\
\hline
\end{tabular}

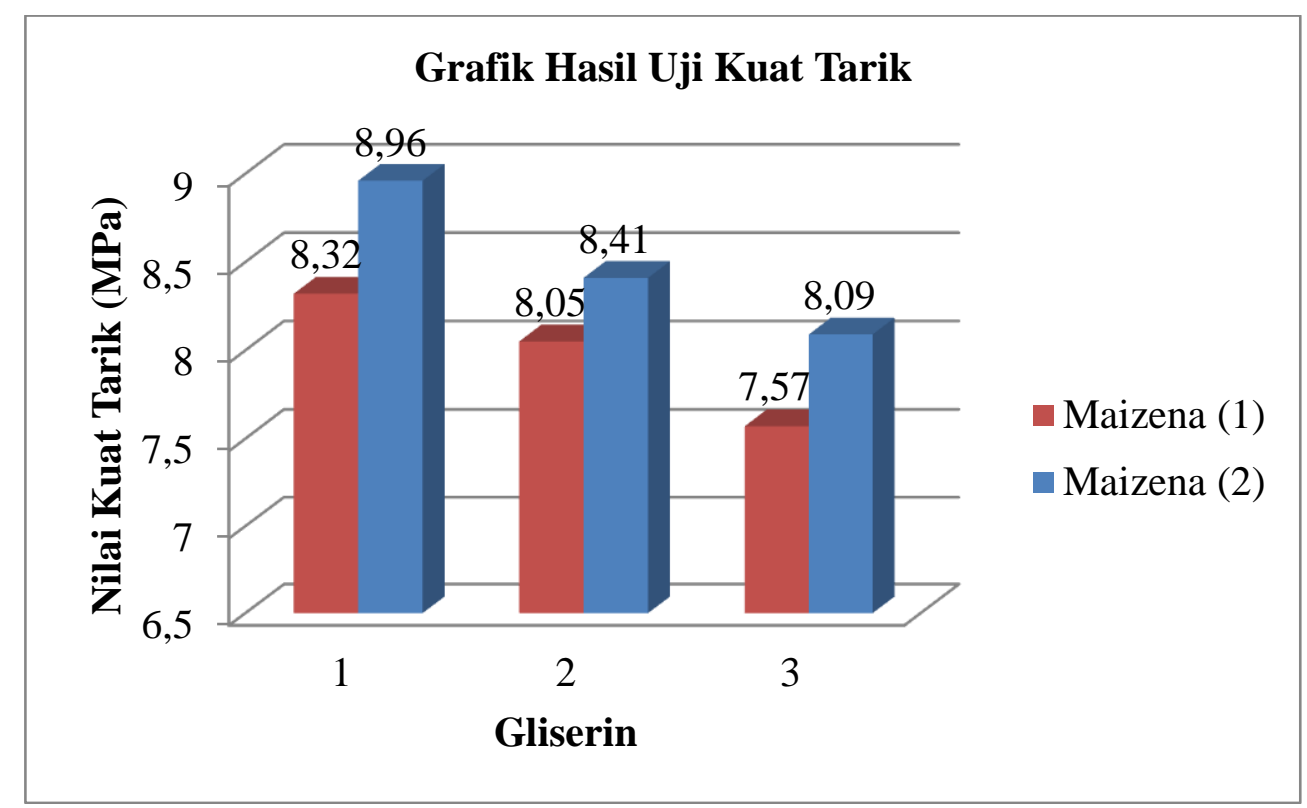

Gambar 2. Grafik pengaruh penambahan maizena dan gliserin terhadap nilai kuat tarik bioplastik.

Berdasarkan grafik pada gambar 2, terlihat bahwa semakin besar perbandingan gliserin yang digunakan maka semakin kecil nilai kuat tarik bioplastik yang dihasilkan. Hal ini disebabkan oleh sifat gliserin yang berfungsi sebagai plastisizer sehingga mempengaruhi kekuatan tarikannya, karena plastisizer dapat mengurangi ikatan hidrogen internal molekul dan menyebabkan gaya tarik intermolekul pada rantai polimer yang berdekatan menjadi melemah sehingga menyebabkan menyebabkan menurunnya nilai kuat tarik bioplastik. Selain itu juga terlihat bahwa semakin besar perbandingan maizena yang digunakan maka semakin besar nilai kuat tariknya. Hal ini dikarenakan banyaknya ikatan hidrogen yang terbentuk akibatnya banyaknya molekul pati dari maizena sehingga menyebabkan semakin rapatnya struktur kimia bioplastik dan akibatnya semakin tinggi nilai kuat tariknya. Dalam penelitian ini didapatkan nilai kuat tarik tertinggi sebesar 8,96 MPa yaitu pada variasi IV dengan perbandingan $4: 2: 1$ dan terendah sebesar 7,57 MPa yaitu pada variasi III dengan perbandingan 4:2:3. 


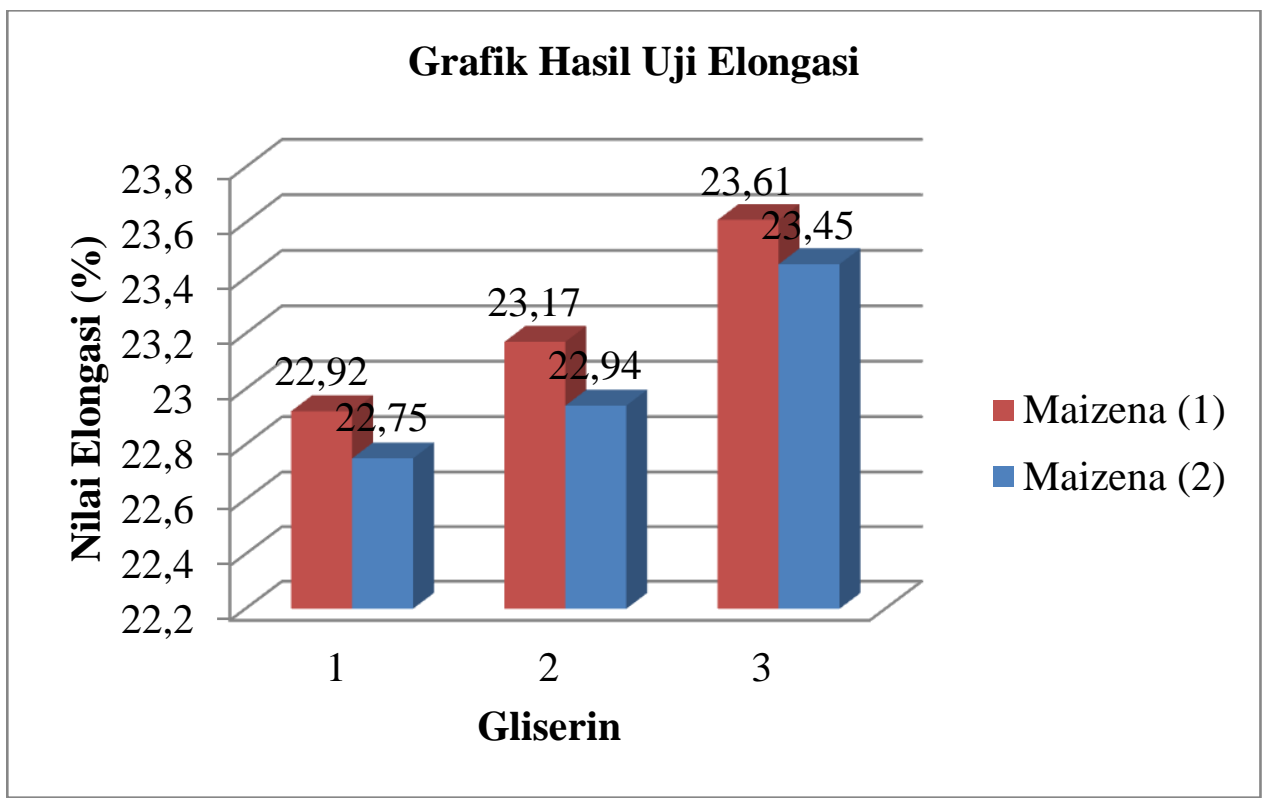

Gambar 3. Pengaruh penambahan maizena dan gliserin terhadap nilai elongasi bioplastik.

Berdasarkan grafik pada gambar 3, terlihat bahwa semakin besar perbandingan gliserin yang digunakan maka semakin besar nilai elongasi bioplastik. Hal ini dikarenakan gliserin yang berfungsi sebagai plastisizer dapat mengurangi ikatan hidrogen internal molekul rantai polimer sehingga menyebabkan jarak intermolekul menjadi meningkat dan bioplastik menjadi semakin elastis.

Selain itu juga terlihat bahwa semakin besar perbandingan maizena yang digunakan maka semakin kecil nilai elongasinya. Hal ini dikarenakan semakin banyaknya maizena menyebabkan semakin banyak molekul pati, akibatnya ikatan hidrogen intermolekul semakin kuat dan rapat sehingga menurunkan keelastisan bioplastik. Nilai kuat tarik dengan nilai elongasi saling berbanding terbalik baik dari variasi perbandingan maizena maupun gliserin. Dalam penelitian ini didapatkan nilai elongasi tertinggi sebesar $23,61 \%$ yaitu pada variasi III dengan perbandingan $4: 1$ : 3 dan nilai elongasi terendah sebesar 22,75 $\%$ yaitu pada variasi IV dengan perbandingan $4: 2: 1$. 


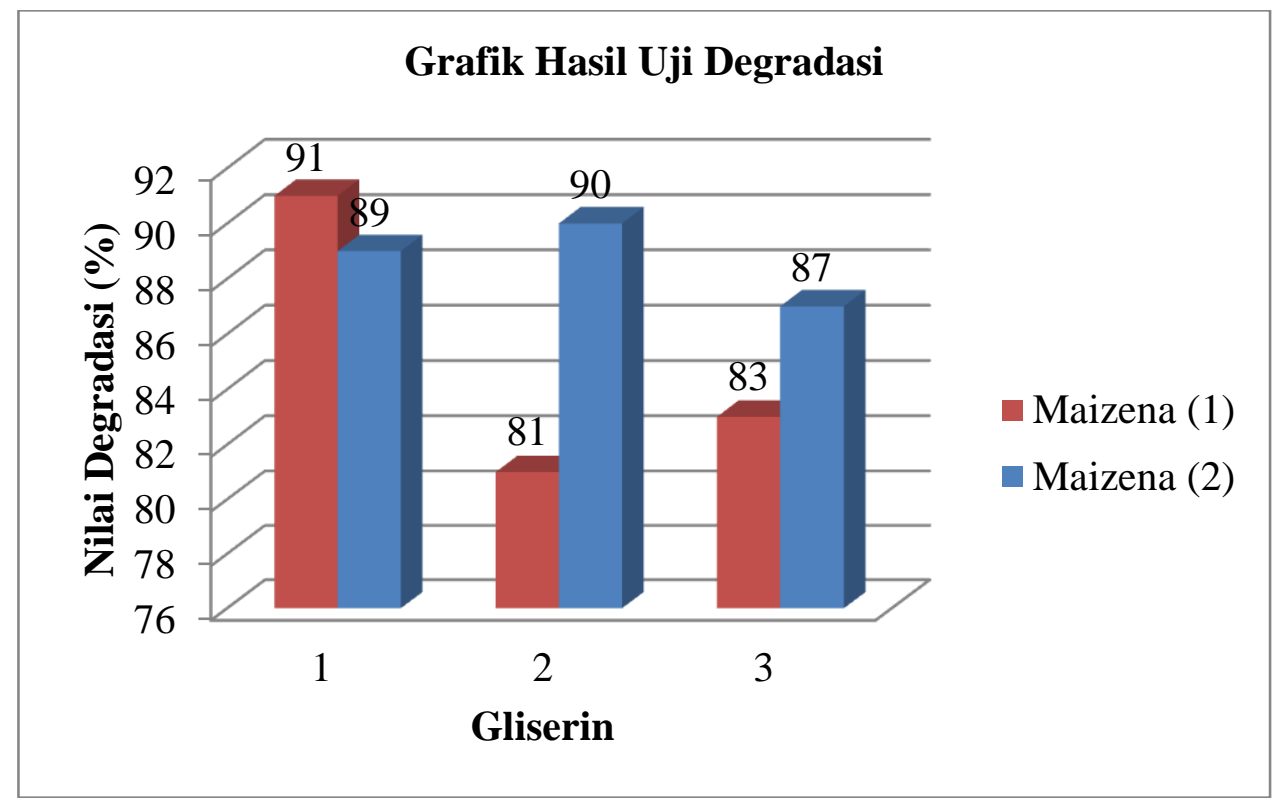

Gambar 4. Pengaruh penambahan maizena dan gliserin terhadap nilai degradasi bioplastik.

Pada pengujian degradasi bioplastik dilakukan berdasarkan perhitungan massa dan dalam satuan persen.

$$
\begin{aligned}
& \text { Nilai degradasi }(\%) \\
& =\frac{\text { Massa awal }- \text { Massa akhir }}{\text { Massa awal }} \times 100 \%
\end{aligned}
$$

Dalam pengujian ini disiapkan 1 gram sampel untuk setiap variasi bioplastik, kemudian diuji dengan cara menanamnya di dalam tanah dan dibiarkan selama 3 minggu. Setelah itu, sampel ditimbang kembali dan dihitung berapa banyak sampel yang terdegradasi untuk menentukan besarnya nilai degradasi bioplastik. Berdasarkan grafik pada gambar 4, terlihat bahwa nilai degradasi tertinggi sebesar $91 \%$ yaitu pada variasi I dengan perbandingan $4: 1: 1$ dan nilai degradasi terendah sebesar $81 \%$ yaitu pada variasi II dengan perbandingan $4: 1: 2$. Pada pengujian ini tidak terlihat jelas pengaruh penambahan variasi maizena dan gliserin pada bioplastik, akan tetapi hasil uji setiap variasi memiliki nilai degradasi yang cukup tinggi yaitu diatas $80 \%$.

\section{KESIMPULAN}

Berdasarkan data-data dalam pembahasan, dapat disimpulkan bahwa:

1. Semakin besar gliserin yang ditambahkan, maka dapat menurunkan nilai kuat tarik tetapi dapat meningkatkan nilai elongasi. Seperti pada variasi I, nilai kuat tarik sebesar 8,32 $\mathrm{MPa}$ dan nilai elongasi sebesar 22,92\%. Sedangkan pada variasi III nilai kuat tarik sebesar 7,57 $\mathrm{MPa}$ dan nilai elongasi sebesar $23,61 \%$.

2. Semakin besar maizena yang ditambahkan, maka dapat meningkatkan nilai kuat tarik tetapi dapat menurunkan nilai elongasi. Seperti pada variasi II, nilai kuat tarik sebesar 8,05 MPa dan nilai elongasi sebesar $23,17 \%$. Sedangkan pada variasi $\mathrm{V}$ nilai kuat tarik sebesar 8,41 $\mathrm{MPa}$ dan nilai elongasi sebesar 22,94\%.

3. Bioplastik dari pelepah kelapa sawit dapat terdegradasi dalam waktu yang relatif cepat, dimana hal itu ditunjukkan dari nilai degradasi yang diatas $80 \%$ untuk setiap variasi bioplastik. 


\section{DAFTAR PUSTAKA}

Badan Pusat Statistik Provinsi Riau, (2011), Luas Perkebunan Sawit Provinsi Riau, http://riau.bps.go.id/publikasion line/riaudalamangka2010/Perkebu nan.html, Diakses tanggal Februari 2013.

Bahmid, N. A., Syamsu, K., Maddu, A., (2013), Production of cellulose acetate from oil palm empty fruit bunches cellulose, J Chem Process Eng, 17 : 12-20.

Charles, A \& Harper, (1999), Modren Plastick Handbook, Mc-Graw- Hill, Lutherville, Maryland.

Firdaus, F, \& Chairil, A., (2004), $\quad$ Potensi Limbah Padat Cair Industri Tepung Tapioka Sebagai Bahan Baku Film Plastik Biodegradable, Jurnal Logika, $1(2)$.

Harpendi, R., Padil., Yelmida., (2014), Proses

Pemurnian Selulosa Pelepah Sawit Sebagai Bahan Baku Nitroselulosa Dengan Variasi Ph Dan Konsentrasi $\mathrm{H}_{2} \mathrm{O}_{2}, 1(1)$, Universitas Riau.

Kumar, S., Panda, A. K., Singh, R. K., (2011), $A$ Review on Tertiary Recycling of High-Density Polyethylene to Fuel, Resources, Conservation and Recycling, 55 : 893-910.

Litbang Deptan, (2010), Pengolahan Pelepah Kelapa Sawit menjadi Pakan, http://lolitkambing.litbang.deptan.go.id/in d/images/stories/pdf/pakan_komplipelepah sawit.pdf, Diakses tanggal 2 Agustus 2012.

Padil, (2010), Proses Pembuatan Nitroselulosa Berbahan Baku Biomassa Sawit, Seminar Nasional Fakultas Teknik UR, ISBN 978-602-96729-0-9.

Padil dan Yelmida, (2009), Produksi NitroSelulosa Sebagai Bahan Baku Propelan yang Berbasis Limbah Padat Sawit, Laporan Penelitian Hibah Penelitian Stranas Batch II, Universitas Riau.

Pahlevi, M. R, (2012), Sampah Plastik, file://II:/Artike1\%20plastic\%20to\%20oil/tw it-sampahplastik.html, Diakses tanggal 1 Juli 2017.
Pranamuda, (2009), Pengembangan Bahan Plastik Biodegradabel Berbahan baku PatiTropis,http://wwwstd.ryu.titech.ac.jp/ indonesia/zoa/paper/htmL/paperHardani ngPranamuda. HtmL, Diakses tanggal 12 November 2011.

Syamsir, E., (2008), Plastik dari senyawa limonene,http://www.chemistry.org/artike 1, Diakses Tanggal 09 November 2011.

Widodo, L. U., Wawan, S., Arif, B. Y., (2010), Kajian pembuatan alpha selulosa dari batang pisang sebagai bahan baku alternatif pembuatan kertas dengan proses delignifikasi, Makalah seminar nasional teknik kimia ketahanan pangan dan energi, ISSN 1978- 0427. 